\title{
Changes of serum angiogenic factors concentrations in patients with diabetes and unstable angina pectoris
}

\author{
Chun Gui ${ }^{\dagger}$, Shi-kang Li ${ }^{\dagger}$, Qin-ling Nong, Fang Du, Li-guang Zhu and Zhi-yu Zeng ${ }^{*}$
}

\begin{abstract}
Backgroud: Diabetic microvascular changes are considered to be influenced by angiogenic factors. As a compensatory mechanism, the expression of some angiogenic factors are elevated in ischemic myocardium. The aim of this study was to investigate the changes of serum angiogenic factors, and the association among these angiogenic factors, the severity of coronary artery stenosis and collateral vessels form in patients with diabetes and unstable angina pectoris (UAP).

Methods: 42 patients with diabetes (diabetes group), 57 patients with UAP (UAP group), and 36 age-matched healthy people (control group) were selected. Serum concentrations of angiogenic factors were measured using cytokine array technology. The severity of coronary artery stenosis was scored using the angiographic Gensini score. Coronary collateral vessels were scored according to Rentrop's classification.

Results: No significant differences in the serum concentrations of vascular endothelial growth factor (VEGF), angiopoietin-1 (Ang-1), angiopoietin-2 (Ang-2), angiogenin, angiostatin, basic fibroblast growth factor (bFGF) and platelet-derived growth factor-BB (PDGF-BB) were detected between control group and diabetes group. But in patients with diabetes complicated with UAP and in patients with UAP without diabetes, serum concentrations of VEGF and Ang-2 were elevated $(p<0.01, p<0.01)$. Only serum Ang-2 concentrations were significantly correlated with Gensini score $(r=0.585, p<0.001)$, left ventricular end diastolic diameter $(r=0.501, p<0.001)$, left ventricular end systolic diameter $(r=0.563, p<0.001)$ and left ventricular ejection fraction $(r=-0.523, p<0.001)$.

Conclusion: Serum concentrations of VEGF and Ang-2 were increased, and diabetes didn't affect this increases in patients with UAP. Serum Ang-2 concentrations were correlated with the severity of coronary artery stenosis.
\end{abstract}

Keywords: Diabetes, Unstable angina pectoris, Angiogenic factors, Gensini score, Collateral vessels

\section{Introduction}

Diabetes mellitus is defined as a metabolic disorder, and is an independent risk factor for a variety of cardiovascular diseases. The causes of accelerated cardiovascular disease in diabetic patients are multifactorial, including coronary artery disease and microvascular pathology. In myocardium of diabetes, microvessels density is significantly reduced, which is reflected by a significant decrease in blood flow [1,2]. In patients with diabetes, the ability to respond to progressive coronary artery stenosis

\footnotetext{
*Correspondence: Drzhiyuzeng@126.com

${ }^{\dagger}$ Equal contributors

Department of Cardiology, the First Affiliated Hospital, Guangxi Medical University, 22 Shuangyong Road, Nanning 530021, Guangxi, People's Republic of China
}

by growing coronary artery collaterals is also significantly impaired $[3,4]$. These microvascular changes may lead to reduced perfusion of myocardium and contribute to adverse cardiovascular events $[5,6]$.

Angiogenesis is a highly regulated process, requires coordinated signaling events among a variety of angiogenic factors. Diabetic microvascular complications are considered to be influenced by angiogenic factors. Vascular endothelial growth factor (VEGF), angiopoietin-1 (Ang-1) and angiopoietin-2 (Ang-2) play crucial roles in developmental blood vessel formation and regulation of hypoxia-induced tissue angiogenesis [7-9]. In addition, some other angiogenic factors and protein are also involved in angiogenesis, such as angiogenin [10],

\section{Biomed Central}

(C) 2013 Gui et al.; licensee BioMed Central Ltd. This is an Open Access article distributed under the terms of the Creative Commons Attribution License (http://creativecommons.org/licenses/by/2.0), which permits unrestricted use, distribution, and reproduction in any medium, provided the original work is properly cited. 
angiostatin [11], basic fibroblast growth factor (bFGF) [12] and platelet-derived growth factor-BB (PDGF-BB) [13]. Previous studies have reported that the expression of VEGF and Ang-1 were reduced, but angiostatin was elevated in the diabetic myocardium $[14,15]$. However, the changes of angiogenic factors expression in local tissues are not always consistent with the changes of systemic concentrations. Some studies reported that the serum VEGF concentrations were no changed in diabetes alone $[16,17]$, but were elevated in diabetes with atherosclerosis or diabetic retinopathy [18]. As a compensatory mechanism, the expression of some angiogenic factors are elevated in ischemic myocardium [19]. Some studies showed serum concentrations and myocardial expression of VEGF and Ang-2 were increased in acute coronary syndrome [20-22].

However, little studies reported the association among circulating angiogenic factors, the severity of coronary artery stenosis and collateral vessels form in patients with diabetes and unstable angina pectoris (UAP). Therefore, using protein array technology, we examined the changes of serum angiogenic factors, including VEGF, Ang-1, Ang-2, angiogenin, angiostatin, bFGF and PDGF-BB, and the association among these angiogenic factors, the severity of coronary artery stenosis and collateral vessels form in patients with diabetes and UAP.

\section{Methods}

\section{Patients recruitment and data collection}

This study was approved by the Human Research Ethics Committee of the first affiliated hospital of guangxi medical university. Informed consent was obtained from all patients. 42 patients with diabetes (diabetes group) and 57 patients with UAP (UAP group) were selected for study group, and 36 age-matched healthy people from medical examination center were selected as control group. The UAP group was divided into diabetes subgroup (23 cases, UAP(DM) subgroup) and non-diabetes subgroup (34 cases, UAP(non-DM) subgroup) according to UAP with or without diabetes. UAP was defined as the presence of typical angina at rest or on minimum exertion associated with acute and transient ST-T segment ECG changes but with normal cardiac enzymes. Exclusion criteria included symptomatic peripheral vascular diseases, renal failure, liver diseases, malignancy, connective tissue diseases, evidence of ongoing infection or inflammation, significant valvular heart diseases and atrial fibrillation.

For each patient, a data sheet was completed with the patient's name, identification number, age, gender, history of hypertension, cigarette smoking, family history of coronary artery disease, and the results of laboratory measurement. On a separate sheet, the patient's Gensini score and collateral score were recorded by experienced angiographers.

\section{Blood collection}

Venous blood samples were taken from the patients with diabetes and UAP on the next morning after admission, and were taken from control group at the time of medical examination. The blood samples were placed the dry tube without anticoagulant for half an hour at room temperature, and then were centrifuged at 3000 $\mathrm{rpm}$ for $5 \mathrm{~min}$. Serum supernatant was removed, and stored at $-80^{\circ} \mathrm{C}$ to be used in angiogenic factors level assays. Serum concentrations of angiogenic factors were measured by protein array.

\section{Measurement of angiogenic factors}

Serum concentrations of angiogenic factors were measured using cytokine array technology (RayBiotech, Inc). Briefly, 100ul sample diluent were added into each well and incubated at room temperature for $30 \mathrm{~min}$ to block slides. And then 100ul standard cytokines or samples were added to each well, and incubated at room temperature for $2 \mathrm{~h}$. Arrays were washed 5 times. 80ul of the detection antibody cocktail were added to each well, and incubated at room temperature for $2 \mathrm{~h}$. Arrays were washed 5 times. 80ul of Cy3 equivalent dye-conjugated streptavidin were added to each well, and incubated at room temperature in dark room for $1 \mathrm{~h}$. Arrays were washed 5 times. Finally, the signals were visualized through use of a laser scanner equipped with a Cy3 wavelength. Data extraction were done with the microarray analysis software.

\section{Measurement of coronary artery stenosis and collateral vessels}

Coronary artery stenosis and collateral vessels were measured using coronary angiography. Standard angiography, with 4 views of the left coronary artery and 2 views of the right coronary artery, was used for interpretation. The severity of coronary artery stenosis was scored using the angiographic Gensini score [23]. Coronary collateral vessels were scored according to Rentrop's classification [24]. A grade of 0 was given for no visible collaterals, 1 for small side branches filled, 2 for major side branches of the main epicardial vessel filled, and 3 for main epicardial vessel filled by collaterals. The angiograms were reviewed and the severity of coronary artery stenosis and collateral vessels were scored by an experienced angiographer, and then reviewed by a separate angiographer who was blinded to the initial reading. In cases of disagreement, angiograms were reviewed by a third angiographer who was blinded to the initial 2 readings and served as an arbitrator. 


\section{Statistical analysis}

The numerical values were expressed as the mean \pm SD. The data were analyzed using the SPSS12.0 statistical software. Comparisons between groups were performed by one-way ANOVA with S-N-K post hoc multiple comparisons and independent-samples $T$ test. The correlations among study parameters were analyzed by Pearson's correlation test and multivariate linear regression analysis. Statistical significance was defined as $\mathrm{p}<0.05$.

\section{Results}

\section{Patient characteristics and clinical data}

The baseline clinical data were summarized in Table 1 . No significant differences existed between groups in terms of age, gender, total cholesterol, HDL cholesterol, LDL cholesterol, Triglycerides. As expected, patients with diabetes had significantly higher levels of glycated hemoglobin (HbA1c), fasting blood glucose (FBG) and 2-h postprandial blood glucose (PBG2h) compared with nondiabetic patients $(\mathrm{p}<0.01)$. In addition, compared with $\mathrm{UAP}(\mathrm{DM})$ subgroup, serum levels of HbA1c, FBG and PBG2h were significantly increased in diabetes group.
In diabetes group, there were 16 patients with albuminuria, 5 patients with peripheral neuropathy. In UAP (DM) subgroup, there were 9 patients with albuminuria, 3 patients with peripheral neuropathy. There were not clinical evidence of other complications.

\section{Changes of serum angiogenic factor concentrations in diabetic patients}

Serum concentrations of VEGF, Ang-1, Ang-2, Angiogenin, Angiostatin, bFGF and PDGF-BB were measured using cytokine array technology. The results showed there were no significant differences in the serum concentrations of all 7 angiogenic factors between control group and diabetes group. We also examined the serum concentrations of angiogenic factors in diabetic patients with UAP. The results showed the serum concentrations of VEGF and Ang-2 were significantly increased, and the serum concentrations of the other angiogenic factors were not changed in diabetic patients with UAP compared with control group (Table 2).

\section{Changes of serum angiogenic factor concentrations in patients with UAP}

The results showed the serum concentrations of VEGF and Ang-2 were significantly increased in UAP group compared

Table 1 Baseline clinical characteristics of all subjects

\begin{tabular}{|c|c|c|c|c|c|}
\hline & $\begin{array}{l}\text { Control } \\
(n=36)\end{array}$ & $\begin{array}{c}\text { Diabetes } \\
(n=42)\end{array}$ & $\begin{array}{l}\text { UAP(DM) } \\
(n=23)\end{array}$ & $\begin{array}{c}\text { UAP(non-DM) } \\
(n=34)\end{array}$ & P Value \\
\hline Age (years) & $59.2 \pm 7.5$ & $55.92 \pm 14.72$ & $59.3 \pm 8.65$ & $60.52 \pm 9.86$ & NS \\
\hline Male, n (\%) & $21(58)$ & $23(57)$ & $14(61)$ & $22(64)$ & NS \\
\hline Smoking, n (\%) & $11(30)$ & $13(31)$ & $8(34)$ & $13(38)$ & NS \\
\hline Hypertension n (\%) & $0(0)$ & $17(40)$ & $14(60)$ & $18(53)$ & $<0.01$ \\
\hline Total cholesterol (mmol/l) & $4.37 \pm 1.23$ & $4.69 \pm 1.02$ & $4.40 \pm 1.12$ & $4.62 \pm 1.35$ & NS \\
\hline HDL cholesterol (mmol/l) & $1.25 \pm 0.46$ & $1.30 \pm 0.40$ & $1.32 \pm 0.42$ & $1.53 \pm 0.54$ & NS \\
\hline LDL cholesterol (mmol/l) & $2.83 \pm 0.96$ & $3.07 \pm 0.823$ & $2.53 \pm 1.44$ & $2.75 \pm 1.05$ & NS \\
\hline Triglycerides (mmol/l) & $1.65 \pm 1.32$ & $1.95 \pm 1.50$ & $1.89 \pm 1.76$ & $1.79 \pm 1.68$ & NS \\
\hline HbA1c (\%) & - & $9.09 \pm 3.01$ & $8.33 \pm 3.52$ & $5.62 \pm 0.86$ & $<0.01$ \\
\hline $\mathrm{FBG}(\mathrm{mmol} / \mathrm{L})$ & $5.36 \pm 1.82$ & $11.84 \pm 6.67$ & $8.3 \pm 4.1$ & $6.13 \pm 1.34$ & $<0.01$ \\
\hline PBG2h (mmol/L) & - & $14.55 \pm 7.75$ & $11.23 \pm 6.31$ & $7.32 \pm 1.51$ & $<0.01$ \\
\hline Diabetes duration (year) & - & $5.61 \pm 2.95$ & $6.48 \pm 3.62$ & - & NS \\
\hline \multicolumn{6}{|l|}{ Medications, n (\%) } \\
\hline Insulin & - & $6(14)$ & $3(13)$ & - & NS \\
\hline Antidiabetics & - & $19(45)$ & $13(56)$ & - & NS \\
\hline Statin & - & $15(35)$ & $19(83)$ & $26(76)$ & $<0.01$ \\
\hline Aspirin & - & $17(40)$ & $21(91)$ & $29(85)$ & $<0.01$ \\
\hline Clopidogrel & - & $0(0)$ & $5(22)$ & $6(18)$ & $<0.01$ \\
\hline ACE inhibitor & - & $11(26)$ & $12(52)$ & $16(47)$ & $<0.01$ \\
\hline Beta-receptors blocker & - & $3(7)$ & $7(30)$ & $13(38)$ & $<0.01$ \\
\hline Nitroglycerin & - & $0(0)$ & $8(35)$ & $13(38)$ & $<0.01$ \\
\hline
\end{tabular}


Table 2 Serum concentrations of angiogenic factors in different groups (pg/ml)

\begin{tabular}{lcccc}
\hline & $\begin{array}{c}\text { Control } \\
(\mathbf{n}=\mathbf{3 6})\end{array}$ & $\begin{array}{c}\text { Diabetes } \\
(\mathbf{n = 4 2})\end{array}$ & $\begin{array}{c}\text { UAP(DM) } \\
(\mathbf{n}=\mathbf{2 3})\end{array}$ & $\begin{array}{c}\text { P value } \\
(\text { ANOVA) }\end{array}$ \\
\hline Angiogenin & $4403.05 \pm 850.27$ & $4432.91 \pm 1009.52$ & $4375.56 \pm 911.94$ & 0.879 \\
Ang-1 & $38647.4 \pm 17964.15$ & $39672.61 \pm 14701.38$ & $45267.17 \pm 17279.20$ & 0.205 \\
Ang-2 & $2444.50 \pm 1152.21$ & $2864.76 \pm 1436.20$ & $3532.10 \pm 1813.72$ & $<0.01$ \\
Angiostatin & $7282.67 \pm 2678.44$ & $6602.22 \pm 2357.75$ & $8145.66 \pm 3600.28$ & 0.163 \\
bFGF & $890.05 \pm 518.09$ & $932.81 \pm 384.60$ & $767.36 \pm 546.01$ & 0.252 \\
PDGF-BB & $10986.56 \pm 5571.85$ & $10264.32 \pm 5427.67$ & $10737.34 \pm 2851.41$ & 0.836 \\
VEGF & $171.92 \pm 106.63$ & $239.24 \pm 115.80$ & $286.90 \pm 217.01$ & $<0.01$ \\
\hline
\end{tabular}

with the control group $(\mathrm{p}<0.01, \mathrm{p}<0.01)$. Whereas, no significant differences in the serum concentrations of angiogenin, Ang-1, angiostatin, bFGF and PDGF-BB were detected between control group and UAP group (Table 3).

In order to observe the influence of diabetes on the serum concentrations of angiogenic factors in patients with UAP, we compared the serum concentrations of angiogenic factors between UAP patients with and without diabetes. The results showed there were no significant differences in the serum concentrations of all 7 angiogenic factors between $\mathrm{UAP}(\mathrm{DM})$ subgroup and UAP(non-DM) subgroup (Table 4).

\section{Correlation of angiogenic factors with other parameters} All 57 patients with UAP were undergone coronary angiography. The Table 5 showed the echocardiographic parameters, Gensini score, collateral score and serum NTproBNP concentrations. By Pearson's correlation and multivariate linear regression analysis in UAP group, serum VEGF and Ang-2 concentrations were unrelated to total cholesterol, HDL cholesterol, LDL cholesterol, triglycerides, HbA1c, FBG, PBG2h, serum NT-proBNP concentrations and collaterals score. Serum Ang-2 concentrations, but not VEGF concentrations, were significantly correlated with
Gensini score, left ventricular end diastolic diameter (LVEDD), left ventricular end systolic diameter (LVESD) and left ventricular ejection fraction (LVEF) (Figure 1, Figure 2).

\section{Discussion}

This is the first study simultaneously investigating circulating levels of 7 angiogenic factors in patients with diabetes and UAP. This study found that: (1) There were no significant differences in the serum concentrations of all 7 angiogenic factors between control group and diabetes group; (2) Serum concentrations of VEGF and Ang-2 were elevated in UAP patients with or without diabetes, and diabetes didn't affect the elevation of serum VEGF and Ang-2 concentrations; (3) Only serum Ang-2 concentrations were significantly correlated with Gensini score, LVEDD, LVESD and LVEF.

\section{Changes of the serum concentrations of angiogenic factors in diabetes alone}

Many studies have demonstrated the alterations of various angiogenic factors in local tissues in the setting of diabetes. It is established that VEGF expression in diabetic myocardium is decreased $[2,14,25]$. Huang et al. reported that
Table 3 Serum angiogenic factors concentrations in control and UAP group $(\mathrm{pg} / \mathrm{ml})$

\begin{tabular}{lccc}
\hline & $\begin{array}{c}\text { Control } \\
(\mathbf{n}=\mathbf{3 6})\end{array}$ & $\begin{array}{c}\text { UAP } \\
(\mathbf{n}=\mathbf{5 7})\end{array}$ & $\begin{array}{c}\text { P value } \\
(\boldsymbol{T} \text { test })\end{array}$ \\
\hline Angiogenin & $4403.05 \pm 850.27$ & $4091.73 \pm 784.89$ & 0.105 \\
Ang-1 & $38647.4 \pm 17964.15$ & $41182.45 \pm 13633.35$ & 0.456 \\
Ang-2 & $2444.50 \pm 1152.21$ & $3679.91 \pm 1880.94$ & $<0.01$ \\
Angiostatin & $7282.67 \pm 2678.44$ & $7661.21 \pm 3283.94$ & 0.593 \\
bFGF & $890.05 \pm 518.09$ & $757.32 \pm 544.35$ & 0.191 \\
PDGF-BB & $10986.56 \pm 5571.85$ & $10880.50 \pm 2307.80$ & 0.941 \\
VEGF & $171.92 \pm 106.63$ & $319.35 \pm 242.59$ & $<0.01$ \\
\hline
\end{tabular}

Table 4 Serum angiogenic factors concentrations in UAP with or without diabetes subgroup $(\mathrm{pg} / \mathrm{ml})$

\begin{tabular}{lccc}
\hline & $\begin{array}{c}\text { UAP(DM) } \\
(\mathbf{n}=\mathbf{2 3})\end{array}$ & $\begin{array}{c}\text { UAP(non-DM) } \\
(\mathbf{n}=\mathbf{3 4 )}\end{array}$ & $\begin{array}{c}\text { P value } \\
(\boldsymbol{T} \text { test })\end{array}$ \\
\hline Angiogenin & $4375.56 \pm 911.94$ & $3914.33 \pm 663.69$ & 0.077 \\
Ang-1 & $45267.17 \pm 17279.20$ & $38629.50 \pm 10609$ & 0.072 \\
Ang-2 & $3532.10 \pm 1813.72$ & $3773.30 \pm 1812.38$ & 0.633 \\
Angiostatin & $8145.66 \pm 3600.28$ & $7358.43 \pm 3153.14$ & 0.357 \\
bFGF & $767.36 \pm 546.01$ & $748.53 \pm 558.83$ & 0.891 \\
PDGF-BB & $10737.34 \pm 2851.41$ & $10969.97 \pm 1994.01$ & 0.714 \\
VEGF & $286.90 \pm 217.01$ & $339.63 \pm 262.08$ & 0.391 \\
\hline
\end{tabular}


Table 5 Parameters of cardiac function and coronary artery in UAP group

\begin{tabular}{lccc}
\hline & $\begin{array}{c}\text { UAP(DM) } \\
(\mathbf{n}=\mathbf{2 3})\end{array}$ & $\begin{array}{c}\text { UAP(non-DM) } \\
(\mathbf{n = 3 4 )}\end{array}$ & $\begin{array}{c}\text { P Value } \\
(\boldsymbol{T} \text { test })\end{array}$ \\
\hline LVEF $(\%)$ & $56.50 \pm 7.95$ & $59.09 \pm 9.96$ & NS \\
LVEDD $(\mathrm{mm})$ & $54.76 \pm 7.34$ & $52.56 \pm 9.72$ & NS \\
LVESD $(\mathrm{mm})$ & $38.24 \pm 6.72$ & $36.22 \pm 9.65$ & NS \\
Gensini score & $41.04 \pm 24.52$ & $38.59 \pm 22.62$ & NS \\
Collateral score & $0.78 \pm 0.99$ & $0.91 \pm 1.03$ & NS \\
NT-proBNP $(\mathrm{pg} / \mathrm{ml})$ & $1743.87 \pm 2521.32$ & $1513.67 \pm 2102.53$ & NS \\
\hline
\end{tabular}

VEGF production in endothelial progenitor cell in response to high glucose stimulation was significant decreased [26]. But VEGF expression in different tissues is different in diabetes. For example, VEGF expression in the retina and renal glomeruli are increased in diabetes [14]. Circulating VEGF may not entirely reflect expression within the myocardium and endothelial cell, it also may derive from other tissues and cells. Some studies reported the serum VEGF concentrations were not changed in diabetes alone [16,17]. So this study supports the results of previous studies.

Some studies have reported the expression of Ang-1 was reduced, but angiostatin was elevated in the diabetic myocardium [15,27]. However, the changes of angiogenic factors expression in local tissue are not always consistent with the changes of serum concentrations. Lim et al. reported plasma Ang-1 was no changed in diabetes $[28,29]$. Siebert et al. reported the serum angiogenin levels were decreased in diabetic patients [30,31]. But another study reported serum angiogenin concentrations were increased in diabetic children [32]. We detected no significant differences in serum concentrations of all 7 angiogenic factors between control group and diabetes group. The changes of angiogenic factors expression in

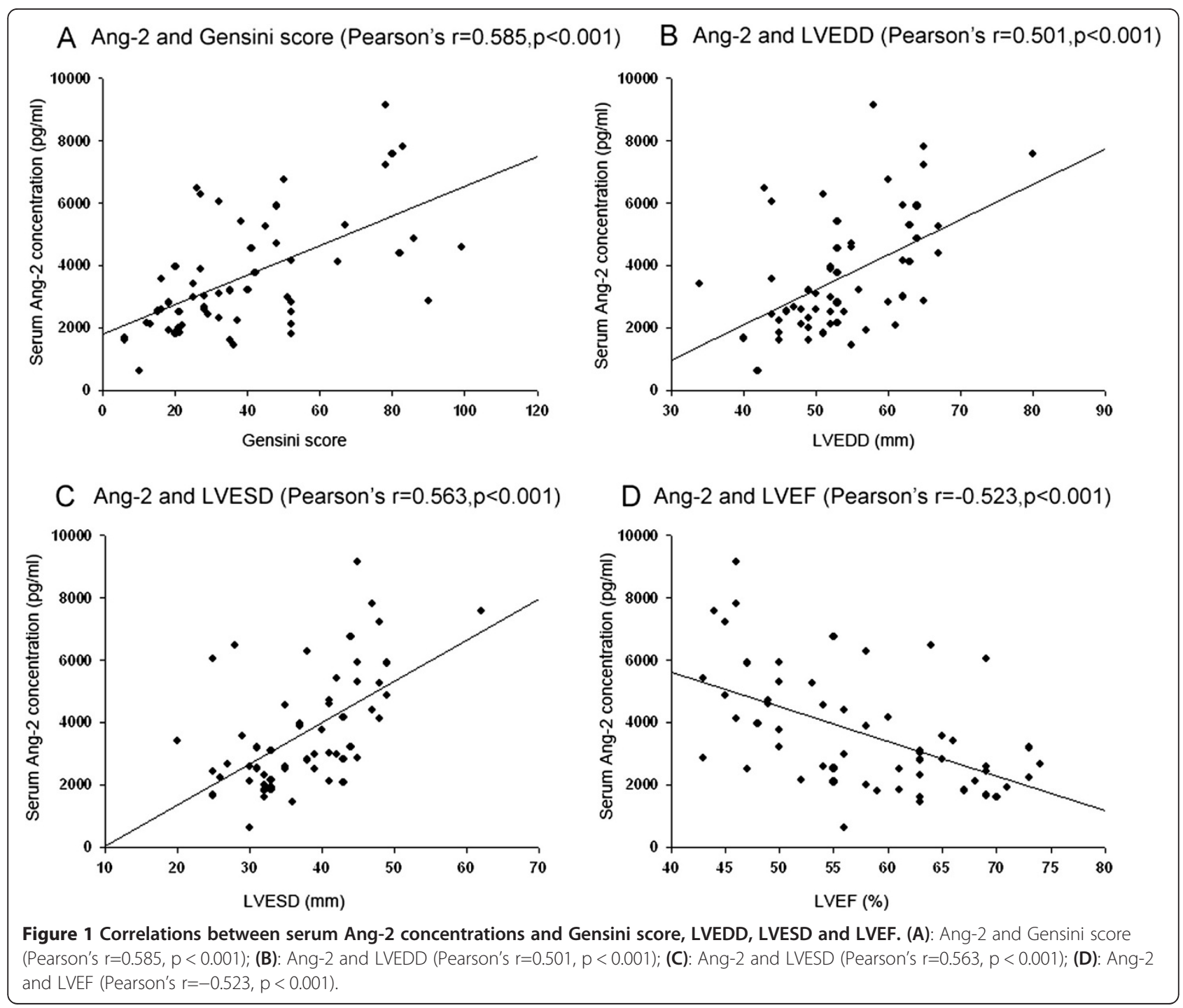




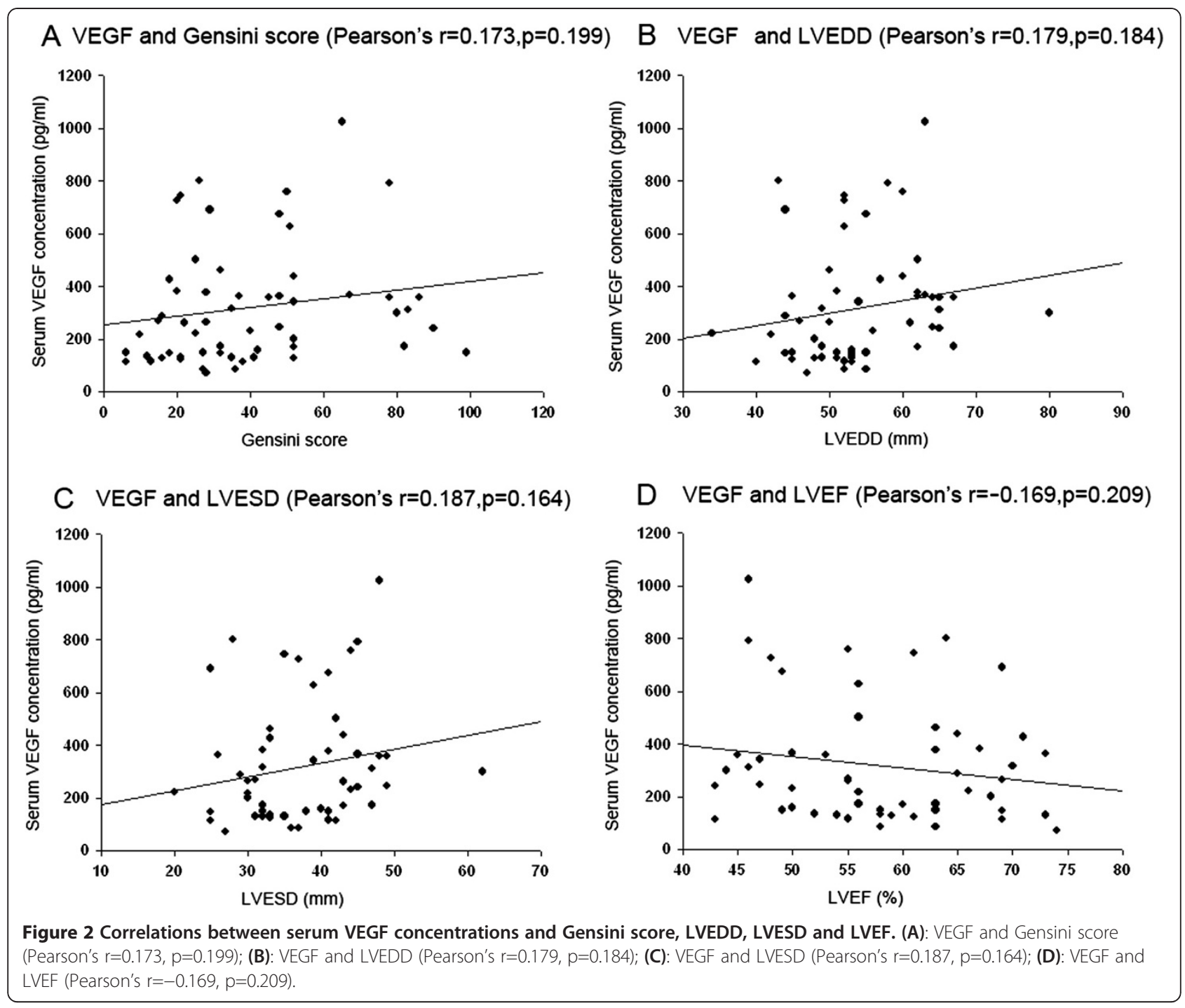

different tissues are different in diabetes, which may cause no differences in serum concertrations.

\section{Changes of the serum concentrations of angiogenic factors in UAP}

Some angiogenic factors can be induced by myocardial ischemia. Matsunaqa et al. reported myocardial expression of VEGF and Ang-2 were increased in coronary heart diseases [20]. Previous studies showed serum concentrations of VEGF and Ang-2 were significantly increased, and Ang-1 were not changed in patients with acute coronary syndrome [21,22]. This study also showed serum concentrations of VEGF and Ang-2 were increased in UAP patients with or without diabetes, which were consistent with previous studies. Antonio et al. reported that plasma angiogenin levels were significantly increased in acute coronary syndromes, but not changed in stable coronary artery disease [33]. The acute coronary syn- dromes in Antonio's study included 49.7\% raised troponin $\mathrm{T}$, which was more severe than that in our study.

Diabetes is associated with reduced expression of myocardial angiogenic factors during ischemia [34]. So this study examined whether the serum concentrations ofangiogenic factors during unstable angina were influenced by diabetes. This study showed there were no significant differences in the serum concentrations of all 7 angiogenic factors between UAP patients with and without diabetes. The expression of angiogenic factors in local tissues, rather than systemic concentrations of angiogenic factors may be influenced by diabetes.

Ang-2 but not VEGF is correlated with the coronary artery stenosis

It is well established that Ang-2 modulates endothelial cell biology and destabilizes blood vessels to facilitate angiogenesis [35]. Ang-2 promotes also VEGF induced 
neovascularization [36,37]. In adult humans, Ang-2 is expressed only at sites of vascular remodeling [38], so circulating levels of Ang-2 may acutely reflect the vascular regeneration and repair. However, VEGF is expressed in many cells, such as endothelial cells, macrophages, smooth muscle cells and cardiocytes. In addition, there is a tremendous interindividual variability in the degree of the hypoxic regulation of VEGF [39]. These factors may be the causes that Ang-2 but not VEGF is correlated with the coronary artery stenosis.

Chong et al. reported plasma Ang-2 and VEGF levels were increased in chronic heart failure, and Ang-2 concentrations were correlated with LVEF [40]. But the etiology of heart failure were not described in Chong's study. Our study showed LVEDD, LVESD and LVEF were significantly correlated with Gensini score. So the interpretation may be that the severity of coronary artery stenosis is the key determinate factor for Ang-2, and the changes in heart dysfunction are merely a reflection of the consequences of stenosis severity. Further research will be needed about the association of Ang-2 and heart failure independent of underlying coronary artery stenosis.

Development of collateral vessels is triggered by the pressure gradient between the coronary arteries bed caused by an obstruction. This study found that patients with well developed collaterals had more severe coronary artery stenosis. Coronary artery stenosis severity other than serum angiogenic factors levels may mainly determine the degree of coronary collateral formation. Some studies have reported some angiogenic protein in pericardial fluid were correlated with coronary collateral growth $[41,42]$. However, Sherman et al. reported that the degree of coronary collateral formation was not determined by differences in systemic levels of angiogenic factors [43]. The expression of angiogenic factors in local tissues, rather than systemic levels of angiogenic factors may affect coronary collateral formation.

\section{Conclusions}

This study showed serum concentrations of VEGF and Ang-2 were increased, and diabetes didn't affect this increases in patients with UAP. Serum Ang-2 concentrations were correlated with the severity of coronary artery stenosis.

\footnotetext{
Abbreviations

UAP: Unstable angina pectoris; DM: Diabetes mellitus; VEGF: Vascular endothelial growth factor; Ang-1: Angiopoietin-1; Ang-2: Angiopoietin-2; bFGF: Basic fibroblast growth factor; PDGF-BB: Platelet-derived growth factorBB; LVEDD: Left ventricular end diastolic diameter; LVESD: Left ventricular end systolic diameter; LVEF: Left ventricular ejection fraction; HbA1c: Glycated hemoglobin; FBG: Fasting blood glucose; PBG2h: 2-h postprandial blood glucose.
}

\section{Competing interests}

The authors declare that they have no competing interests.

\section{Authors' contributions}

ZZ contributed to the design and coordination of the study, CG performed the statistical analysis and drafted the manuscript, SL carried out patient enrollment and protein array test. All authors have read and approved the final manuscript.

\section{Acknowledgments}

This study was supported by National Natural Science Foundation of China (No: 81160021) and Guangxi Natural Science Foundation (No: GXNSFA018223).

Received: 3 January 2013 Accepted: 8 February 2013 Published: 19 February 2013

\section{References}

1. Yoon YS, Uchida S, Masuo O, Cejna M, Park JS, Gwon HC, Kirchmair R, Bahlman F, Walter D, Curry C, Hanley A, Isner JM, Losordo DW: Progressive attenuation of myocardial vascular endothelial growth factor expression is a seminal event in diabetic cardiomyopathy: restoration of microvascular homeostasis and recovery of cardiac function in diabetic cardiomyopathy after replenishment of local vascular endothelial growth factor. Circulation 2005, 111:2073-2085.

2. Han B, Baliqa R, Huang H, Giannone PJ, Bauer JA: Decreased cardiac expression.of vascular endothelial growth factor and redox imbalance in murine diabetic cardiomyopathy. Am J Physiol Heart Circ Physiol 2009, 297: H829-H835.

3. Abaci A, Oguzhan A, Kahraman S, Eryol NK, Unal S, Arinc H, Ergin A: Effect of diabetes mellitus on formation of coronary collateral vessels. Circulation 1999, 99:2239-2242.

4. Nisanci Y, Sezer M, Umman B, Yilmaz E, Mercanoqlu S, Ozsaruhan O: Relationship between pressure-derived collateral blood flow and diabetes mellitus in patients with stable angina pectoris: a study based on coronary pressure measurement. J Invasive Cardiol 2002, 14:118-122.

5. McDonagh PF, Hokama JY: Microvascular perfusion and transport in the diabetic heart. Microcirculation 2000, 7:163-181.

6. De Boer RA, Pinto YM, Van Veldhuisen DJ: The imbalance between oxygen demand and supply as a potential mechanism in the pathophysiology of heart failure: the role of microvascular growth and abnormalities. Microcirculation 2003, 10:113-126.

7. Witzenbichler B, Maisonpierre PC, Jones P, Yancopoulos GD, Isner JM: Chemotactic properties of angiopoietin-1 and -2 , ligands for the endothelial-specific receptor tyrosine kinase Tie2. J Biol Chem 1998, 273:18514-18521.

8. Peters KG: Vascular endothelial growth factor and the angiopoietins: working together to build a better blood vessel. Circ Res 1998, 83:342-343.

9. Yamakawa M, Liu LX, Date T, Belanger AJ, Vincent KA, Akita GY, Kuriyama T, Cheng SH, Gregory RJ, Jiang C: Hypoxia-inducible factor-1 mediates activation of cultured vascular endothelial cells by inducing multiple angiogenic factors. Circ Res 2003, 93:664-673.

10. Kishimoto K, Liu S, Tsuji T, Olson KA, Hu GF: Endogenous angiogenin in endothelial cells is a general requirement for cell proliferation and angiogenesis. Oncogene 2005, 24:445-456.

11. Troyanovsky B, Levchenko T, Mansson G, Matvijenko O, Holmgren L: Angiomotin: an angiostatin binding protein that regulates endothelial cell migration and tube formation. J Cell Biol 2001, 152:1247-1254.

12. Carmeliet $P$ : Mechanisms of angiogenesis and arteriogenesis. Nat Med 2000, 6:389-395.

13. Battegay EJ, Rupp J, Iruela-Arispe L, Saqe EH, Pech M: PDGF-BB modulates endothelial proliferation and angiogenesis in vitro via PDGF betareceptors. J Cell Biol 1994, 125:917-928.

14. Chou E, Suzuma I, Way KJ, Opland D, Clermont AC, Naruse K, Suzuma K, Bowling NL, Vlahos CJ, Aiello LP, King GL: Decreased cardiac expression of vascular endothelial growth factor and its receptors in insulin-resistant and diabetic States: a possible explanation for impaired collateral formation in cardiac tissue. Circulation 2002, 105:373-379.

15. Boodhwani M, Sodha NR, Mieno S, Xu SH, Feng J, Ramlawi B, Clements RT, Sellke FW: Functional, cellular, and molecular characterization of the angiogenic response to chronic myocardial ischemia in diabetes. Circulation 2007, 116:131-1137. 
16. Khazaei M, Fallahzadeh AR, Sharifi MR, Afsharmoghaddam N, Javanmard SH, Salehi E: Effects of diabetes on myocardial capillary density and serum angiogenesis biomarkers in male rats. Clinics (Sao Paulo) 2011, 66:1419-1424.

17. Blann AD, Belgore FM, McCollum CN, Silverman S, Lip PL, Lip GY: Vascular endothelial growth factor and its receptor, Flt-1, in the plasma of patients with coronary or peripheral atherosclerosis, or Type II diabetes. Clin Sci (Lond) 2002, 102:187-194.

18. Ozturk BT, Bozkurt B, Kerimoglu H, Okka M, Kamis U, Gunduz K: Effect of serum cytokines and VEGF levels on diabetic retinopathy and macular thickness. Mol Vis 2009, 15:1906-1914.

19. Hashimoto E, Ogita T, Nakaoka T, Matsuoka R, Takao A, Kira Y: Rapid induction of vascular endothelial growth factor expression by transient ischemia in rat heart. Am J Physiol 1994, 267:H1948-H1954

20. Matsunaqa T, Warltier DC, Tessmer J, Weihrauch D, Simons M, Chilian WM: Expression of VEGF and angiopoietins-1 and -2 during ischemiainduced coronary angiogenesis. Am J Physiol Heart Circ Physiol 2003, 285:H352-H358.

21. Lee KW, Lip GY, Blann AD: Plasma angiopoietin-1, angiopoietin-2, angiopoietin receptor tie-2, and vascular endothelial growth factor levels in acute coronary syndromes. Circulation 2004, 110:2355-2360.

22. Iribarren C, Phelps BH, Darbinian JA, McCluskey ER, Quesenberry CP, Hytopoulos E, Vogelman JH, Orentreich N: Circulating angiopoietins-1 and -2 , angiopoietin receptor Tie-2 and vascular endothelial growth factor-A as biomarkers of acute myocardial infarction: a prospective nested casecontrol study. BMC Cardiovasc Disord 2011, 11:31.

23. Gensini GG: A more meaningful scoring system for determining the severity of coronary heart disease. Am J Cardiol 1983, 51:606.

24. Rentrop KP, Cohen M, Blanke H, Phillips RA: Changes in collateral channel filling immediately after controlled coronary artery occlusion by an angioplasty balloon in human subjects. J Am Coll Cardiol 1985, 5:587-592.

25. Lu J, Yao YY, Dai QM, Ma GS, Zhang SF, Cao L, Ren LQ, Liu NF: Erythropoietin attenuates cardiac dysfunction by increasing myocardial angiogenesis and inhibiting interstitial fibrosis in diabetic rats. Cardiovasc Diabetol 2012, 11:105.

26. Huang $\mathrm{PH}$, Chen JW, Lin CP, Chen $\mathrm{YH}$, Wang CH, Leu HB, Lin SJ: Far infrared therapy promotes ischemia-induced angiogenesis in diabetic mice and restores high glucose-suppressed endothelial progenitor cell functions. Cardiovasc Diabetol 2012, 11:99.

27. Sodha NR, Clements RT, Boodhwani M, Xu SH, Laham RJ, Bianchi C, Sellke FW: Endostatin and angiostatin are increased in diabetic patients with coronary artery disease and associated with impaired coronary collateral formation. Am J Physiol Heart Circ Physiol 2009, 296:H428-H434.

28. Lim HS, Lip GY, Blann AD: Angiopoietin-1 and angiopoietin-2 in diabetes mellitus: relationship to VEGF, glycaemic control, endothelial damage/ dysfunction and atherosclerosis. Atherosclerosis 2005, 180:113-118.

29. Lim HS, Blann AD, Chong AY, Freestone B, Lip GY: Plasma vascular endothelial growth factor, angiopoietin-1, and angiopoietin-2 in diabetes: implications for cardiovascular risk and effects of multifactorial intervention. Diabetes Care 2004, 27:2918-2924.

30. Siebert J, Reiwer-Gostomska M, Babinska Z, Mysliwska J, Mysliwski A Skopinska-Rozewska E, Sommer E, Skopinski P: Low serum angiogenin concentrations in patients with type 2 diabetes. Diabetes Care 2007, 30:3086-3087.

31. Siebert J, Reiwer-Gostomska M, Mysliwska J, Marek N, Raczynska K, Glasner L: Glycemic control influences serum angiogenin concentrations in patients with type 2 diabetes. Diabetes Care 2010, 33:1829-1830.

32. Chiarelli F, Pomilio M, Mohn A, Tumini S, Verrotti A, Mezzetti A, Cipollone F, Wasniewska M, Morgese G, Spagnoli A: Serum angiogenin concentrations in young patients with diabetes mellitus. Eur J Clin Invest 2002, 32:110-114.

33. Tello-Montoliu A, Marin F, Patel J, Roldan V, Mainar L, Vicente V, Sogorb F, Lip GY: Plasma angiogenin levels in acute coronary syndromes: implications for prognosis. Eur Heart J 2007, 28:3006-3011.

34. Marfella R, Esposito K, Nappo F, Siniscalchi M, Sasso FC, Portoghese M, Di Marino MP, Baldi A, Cuzzocrea S, Di Filippo C, Barboso G, Baldi F, Rossi F, D'Amico M, Giugliano D: Expression of Angiogenic Factors During Acute Coronary Syndromes in Human Type 2 Diabetes. Diabetes 2004, 53:2383-2391.

35. Asahara T, Chen D, Takahashi T, Fujikawa K, Kearney M, Magner M, Yancopoulos GD, Isner JM: Tie2 receptor ligands, angiopoietin-1 and angiopoietin-2, modulate VEGF-induced postnatal neovascularization. Circ Res 1998, 83:233-240.
36. Zhu Y, Lee C, Shen F, Du R, Young WL, Yang GY: Angiopoietin-2 facilitates vascular endothelial growth factor-induced angiogenesis in the mature mouse brain. Stroke 2005, 36:1533-1537.

37. Oshima Y, Oshima S, Nambu H, Kachi S, Takahashi K, Umeda N, Shen J, Dong A, Apte RS, Duh E, Hackett SF, Okoye G, Ishibashi K, Handa J, Melia M, Wiegand S, Yancopoulos G, Zack DJ, Campochiaro PA: Different effects of angiopoietin-2 in different vascular beds: new vessels are most sensitive. FASEB J 2005, 19:963-965.

38. Maisonpierre PC, Suri C, Jones PF, Bartunkova S, Wiegand SJ, Radziejewski C, Compton D, McClain J, Aldrich TH, Papadopoulos N, Daly TJ, Davis S, Sato TN, Yancopoulos GD: Angiopoietin-2, a natural antagonist for Tie2 that disrupts in vivo angiogenesis. Science 1997, 277:55-60.

39. Schultz A, Lavie L, Hochberg I, Beyar R, Stone T, Skorecki K, Lavie P, Roguin A, Levy AP: Interindividual Heterogeneity in the Hypoxic Regulation of VEGF: significance for the development of the coronary artery collateral circulation. Circulation 1999, 100:547-552.

40. Chong AY, Caine GJ, Freestone B, Blann AD, Lip GYH: Plasma angiopoietin1 , angiopoietin-2, and angiopoietin receptor tie-2 levels in congestive heart failure. J Am Coll Cardiol 2004, 43:423-428.

41. Panchal VR, Rehman J, Nguyen A, Brown JW, Turrentine M, Mahomed Y, March K: Reduced pericardial levels of endostatin correlate with collateral development in patients with ischemic heart disease. J Am Coll Cardiol 2004, 43:1383-1387.

42. Matsunaga T, Chilian WM, March K: Angiostatin is negatively associated with coronary collateral growth in patients with coronary artery disease. Am J Physiol Heart Circ Physiol 2005, 288(suppl):H2042-H2046.

43. Sherman JA, Hall A, Malenka DJ, De Muinck ED, Simons M: Humoral and cellular factors responsible for coronary collateral formation. Am J Cardiol 2006, 98:1194-1197.

doi:10.1186/1475-2840-12-34

Cite this article as: Gui et al:: Changes of serum angiogenic factors concentrations in patients with diabetes and unstable angina pectoris. Cardiovascular Diabetology 2013 12:34.

\section{Submit your next manuscript to BioMed Central and take full advantage of:}

- Convenient online submission

- Thorough peer review

- No space constraints or color figure charges

- Immediate publication on acceptance

- Inclusion in PubMed, CAS, Scopus and Google Scholar

- Research which is freely available for redistribution

Submit your manuscript at www.biomedcentral.com/submit
C) Biomed Central 